\title{
THE ELECTRIC CONDUCTIVITY AS A PARAMETER FOR MILK QUALITY APPRECIATION
}

\author{
Rodica Caprita, A. Caprita, I. Benscik
}

University of Agricultural Sciences Timisoara, Calea Aradului, 119, RO-1900, Timisoara, ROMANIA

The main components of the milk are: proteins (casein, lactalbumin, lactoglobulin), lactose, fat and mineral salts. The lactose concentration depends on several factors among which the health condition of the cows and the acidifying of the milk. In our days the chlorine/lactose ratio is used as a parameter for appreciating the milk quality. Although milk is isotonic with blood, the two biological liquids are very different in mineral composition, in concentration, and also in the proportion of ionised and bound to proteins forms. The osmotic pressure of the milk remains constant, and therefore when the lactose content is lower, the electrolytes are rising. Mainly, the equilibration is due to the chloride, probably the $\mathrm{NaCl}$. This explains the variation of the electric conductivity.

There were analyzed milk samples from 16 cows in the first lactation period, twice a month, from March to May. The $\mathrm{pH}$ was determined with a digital $\mathrm{pH}$-meter, the conductivity $(\sigma)$ with the conductivity meter type OK-102/1 (Radelkis), the chloride ion was determined by the Mohr method and the lactose by refractometry (refractometer Abbé). The determinations were performed on fresh milk and after 24 hours. $\sigma$ (in $\mathrm{mS} / \mathrm{cm}$ ) is in negative correlation with the lactose content (in $\mathrm{g} \%$ ) [1] and in positive correlation with the chloride ion (in $\mathrm{g} \%$ ), as presented in figure 1 .

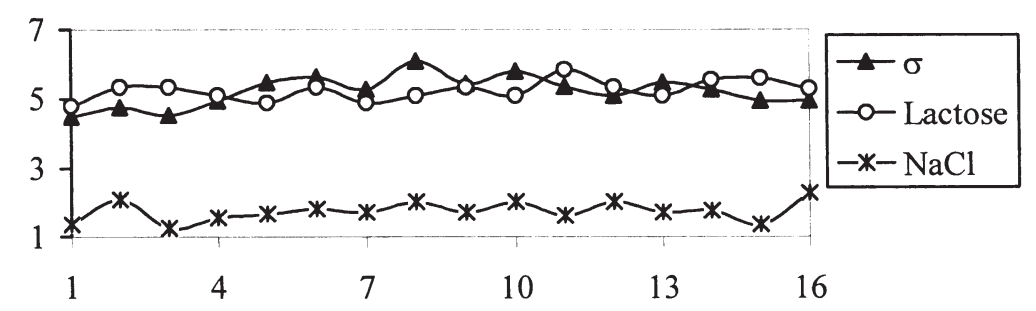

Figure 1. The correlation of the electric conductivity with the lactose and $\mathrm{NaCl}$

We conclude that the electric conductivity may be used for the appreciation of milk quality. High values show in fresh milk a high chlorine/lactose ratio, which occurs in case of mastitis. This method may be used instead of the chlorine/lactose ratio, which is more difficult to determine.

The electric conductivity increases also with the acidifying of the milk when from 1 molecule of lactose 4 molecules of lactic acid are formed due the lactic fermentation of lactose. The proportion of ionic dispersed salts increases too, when casein changes (by acidifying) from calciumcaseinat in free casein

[1] A. Caprita, Rodica Caprita - Annals of West Univ. Timisoara, series Chemistry, 10(2), 375-378, 2001 